\title{
An American Business School's Academic Advising and Professional Development Centers' Early Pandemic Response
}

\author{
Gary Blau ${ }^{1} \&$ Daniel Goldberg ${ }^{1}$ \\ ${ }^{1}$ Human Resource Management Department, Fox School of Business \& Management, Temple University, \\ Philadelphia, PA, United States
}

Correspondence: Gary Blau, Human Resource Management Dept., Fox School of Business \& Management, Alter Hal \#349 (006-00) - 1801 Liacouras Walk, Temple University, Philadelphia 19122, PA, United States. Tel: 1-215-204-6906.

Received: June 6, 2021

Accepted: July 21, 2021

Online Published: July 30, 2021

doi:10.20849/jed.v5i2.910

URL: https://doi.org/10.20849/jed.v5i2.910

\begin{abstract}
As colleges and universities around the world grapple with the continuing impact of the ongoing COVID-19 pandemic, it is necessary for research to not only focus on student academic learning issues, but also test for maintained support of needed student resources such as Academic Advising and Professional Development Centers. Using the Senior Student Satisfaction Survey, two separate samples of graduating business undergraduates at a Mid-Atlantic University in the United States of America were surveyed, in late Spring 2019 (pre-pandemic) and late Spring 2020 (early pandemic). The goals of this study were two-fold. The first was to test for changes from pre-pandemic to early pandemic in seven student-related perception measures: attendance motivation, coursework challenge, professional development engagement, academic advising ease/quality, professional development ease/quality, business degree satisfaction, and perceived market value to potential employers. The second goal was to test for changes in the perceived relationships of five "independent variables", i.e., attendance motivation, coursework challenge, professional development engagement, academic advising center ease/quality, and professional development center ease/quality, to two "dependent variables", i.e., business degree satisfaction and perceived market value to potential employers. Comparing pre-pandemic (2019) to early pandemic (2020) perceptual change data, this study found that both the Academic Advising and Professional Development Centers handled these student-based perception variables from the surveys quite well. When the campus was suddenly closed due to the pandemic, both Centers successfully made quick adaptive changes to virtual models to handle initial student needs.
\end{abstract}

Keywords: pandemic, college academic advising center, college professional development center

\section{Introduction}

\subsection{Introduce the Problem}

Despite recent vaccination advancements, virus variants of the COVID-19 pandemic continue to bring health, economic and social upheaval, and continued cause for concern, to millions of lives around the world (Plater, 2021). It was estimated that COVID-19 cost colleges in the United States $\$ 183$ billion in lost reverie for 2020 (Friga, 2021). Revenue losses forced employee layoffs and department closing at many universities and colleges (Sainato, 2021), and some smaller liberal arts colleges, i.e., Mills College (in California), MacMurray College (in Illinois), and Holy Family College (in Wisconsin) needed to shut down completely. For other colleges, as part of their closure process, e.g., Concordia College (New York) students were allowed to finish their degrees at nearby universities/colleges (Aspegren, 2021). This upheaval in higher level education was felt across the world (Bozkurt et al., 2020). There is still uncertainty about how "normal" college campus life will be in the Fall 2021 for many universities and colleges around the world (McCormack, Lemoine, Waller \& Richardson, 2021). Studies of college students in the early pandemic stage revealed experienced panic with greater COVID-19 fears and increased depressive mood (Hasratian, Nordberg, Meuret \& Riz, 2021), and the need for tailored prevention intervention strategies to recognize student perceived barriers and self-efficacy (Tam, $\mathrm{Li}, \mathrm{Li}$, Wang \& $\mathrm{Lin}, 2021$ ). Managing this return-to-college ambiguity is critical. Highlighting the need for agility and adaptability McCormack et al. (2021) made several general recommendations, including the need for global higher education institutions to: focus on long-range planning over crisis management, and increase awareness/monitoring of 
learning design quality.

Recent articles have been written at a country-level to reinforce these general recommendations in dealing with higher education issues caused by the COVID-19 pandemic, e.g., Singapore, Indonesia, Malaysia and Thailand (Balakrishnan, 2020); Canada and Barbados (Marshall, Roache \& Moody-Marshall (2020), the United Kingdom (Wateryer, Crick, Knight \& Goodall, 2021), and the United States (Fernandez \& Shaw, 2020). Drilling down further, case studies at specific universities for implementing these recommendations should be noted, e.g., Peking University in China (Bao, 2020); Ashesi University in Ghana (Agyepng, Owusu-Ansah \& Annoh, 2021); and the State University of New York Old Westbury branch (Neuwirth, Jovic \& Mukherji, 2020). However, these above-cited studies have focused on college-level teaching issues around the pandemic, (Rapanta, Botturi, Goodyear, Guardia \& Koole, 2020) including: better benchmarking to improve online learning and instructional design, student access to digital skills training and online resources, teacher training in online learning, and stronger virtual work-applied learning simulations for students.

\subsection{Relevant Scholarship}

Much less attention has been given to non-teaching-related college student resources such as academic advising and professional development. Such resources are important for college student retention and graduation (Swecker, Fifolt \& Searby, 2013). With the exception of Blau, Snell and Goldberg (2021) the authors found an absence of specific empirical research and only general recommendations on the need to consider these two non-teaching student resources as a University responded to COVID-19 challenges (Russell et al., 2021). Using two independent graduating business undergraduate samples, across pre and early pandemic periods, Blau et al. (2021) empirically demonstrated the importance of students having at least one internship experience (versus none) for a higher anticipation level by graduation to have subsequent full-time employment. The purpose of this study is to extend Blau et al. (2021) by examining graduating student perceptions to the early pandemic response of academic advising and student professional development at a Business School in the United States. This study incorporates previously untested variables in a general model of student professional engagement developed by Blau and Snell (2013), including student perceptions of: attendance motivation, coursework challenge, academic advising center ease/quality, professional development center ease/quality, business degree satisfaction, and perceived market value to potential employers.

\subsection{Research Question}

The goals of this study were two-fold: (1) test for changes from pre-pandemic to early pandemic in seven student-related perceptions: attendance motivation; coursework challenge, professional development engagement, academic advising ease/quality, professional development ease/quality, business degree satisfaction, and perceived market value to potential employers; and (2) test for changes in the perceived relationships of five "independent variables," i.e., attendance motivation, coursework challenge, professional development engagement, academic advising center ease/quality, and professional development center ease/quality to two "dependent variables," i.e., business degree satisfaction, and perceived market value to potential employers.

\section{Method}

\subsection{Participants and Procedure}

Two independent samples, each made up of graduating undergraduate business students, filled out an online survey. Surveys were done in May, 2019 (pre-pandemic) and May, 2020 (early pandemic) semesters. The state-supported university business school is located in the Mid-Atlantic region of the United States (US). All graduating business seniors were reminded by their advisor and through multiple emails to voluntarily fill out an online Senior Student Satisfaction Survey (SSSS) prior to graduation. All measures collected were part of the SSSS. The measures used below were identical for both surveys. It is important to note that due to the large size of the business school, the business school has its own Academic Advising Center and Center for Student Professional Development (CSPD). The activities of Academic Advising focused on such student-related issues as: proper course registration, accurate student curriculum planning with their advisor, substitution of equivalent courses, and timely graduation. The CSPD focused on such issues as student professional development, career/industry awareness, resume building, interviewing, recruiting/employer-related networking, and presenting internship and job opportunities for students. Separate Qualtrics data bases were used to store the data. In May of 2019, 749 graduating seniors responded by filling out at least part of the SSSS. This participation rate represented about $70 \%$ of the graduating seniors. In May of 2020, 445 students filled out the SSSS, which represented approximately 37\% of the graduating seniors. The sudden shift on March 13, 2020 (approximately half-way through the Spring semester) by the university to all remote (no in-person) classes, and students needing to move out of campus housing due to the pandemic, undoubtedly impacted the May 2020 participating 
sample size. The university institutional review board (IRB) approved the research as part of a general program review. Ninety-six percent of each sample were full-time students (taking at least 12 credits/semester), and had slightly higher male participants $(53 \%$ in $2019 ; 52 \%$ in 2020). For this study only complete data samples were used, consisting of $n=567 / 749$ (76\%) for the 2019 data and $n=285 / 445(64 \%)$ for the 2020 data.

\subsection{Measures}

Attendance Motivation was measured using a four-item scale, based on prior work by Blau, Williams, Jarrell, and Nash (2019). Using the referent, "Rate the importance of the following items in your decision to attend the Business School of this University," on a six-point response scale, from $1=$ strongly unimportant to $6=$ strongly important. A sample item was "specific majors." Blau et al. (2019) found a coefficient alpha of .82. For this study, the coefficient alphas were: 71 (2019) and .69 (2020). Unless otherwise noted below, all measures below used a six-point response scale, from $1=$ strongly disagree to $6=$ strongly agree.

Coursework Challenge consisted of four items, and was measured by asking students "the degree to which you felt challenged in four separate course areas," and a sample item was "global business policies" (the capstone business course). Blau et al. (2019) found a coefficient alpha of .76. For this study, the coefficient alphas were: .80 (2019) and .77 (2020).

Professional Development Engagement was measured using a shortened two-item measure adapted from Blau et al. (2019). The general referent was, "the following career center activities contributed to my professional development." A sample item was, "multiple resume critiques." For this study, the coefficient alphas were: .66 (2019) and .73 (2020).

Academic Advising Center Ease/Quality consisted of two items, a sample item is "undergraduate academic advising is easy to learn about and use the services offered." Blau et al. (2019) found a coefficient alpha of .84. For this study, the coefficient alphas were: .78 (2019) and .86 (2020).

Professional Development Center Ease/Quality was measured using two items, a sample item is "there was a high quality of service provided by the professional development center." Blau, Halbert, Atwater, Kershner and Zuckerman (2016) found a coefficient alpha of .85. For this study, the coefficient alphas were: .81 (2019) and .85 (2020).

Business Degree Satisfaction consisted of a three-item scale, and a sample item was "overall, I am satisfied with my major." Blau et al. (2019) found a coefficient alpha of .85. For this study, the coefficient alphas were: .83 (2019) and .82 (2020).

Market Value to Potential Employers by asking respondents one item, to indicate their level of agreement with the statement, "the reputation of the Business School influences your market value to potential employers." Blau et al. (2016) used this item in their prior work.

\subsection{Data Analyses}

Means, standard deviations, and correlations were separately done for the 2019 and 2020 complete data samples. Then independent sample t-tests were performed to test for mean changes in the seven above-noted perceptual measures from 2019 to 2020. After this, independent sample t-tests were performed for changes in the perceived relationships of five "independent variables," i.e., attendance motivation, coursework challenge, professional development engagement, academic advising center ease/quality, and professional development center ease/quality, to two "dependent variables," i.e., business degree satisfaction, and perceived market value to potential employers. SPSS-PC, version 24 (2018) was used for all data analyses.

\section{Results}

\subsection{Missing Data}

As noted above there were missing data for both samples. For 2019 there was a complete data sample of $\mathrm{n}=567$ out of $749(76 \%)$ respondents. Given this amount of missing data it was important to check for systematic missing data bias (Roth, 1994) prior to testing the research questions. Using an independent samples t-test (missing versus complete data respondents), only one significant difference was found across the seven variables in the 2019 data. The missing data respondents perceived higher Professional Development Center Ease/Quality $(M=4.94)$ than the complete data respondents $(M=4.70), t=2.33(698), p<.05$. For 2020 there was a complete data sample of $\mathrm{n}=285$ out of 445 respondents (64\%). Using an independent samples t-test (missing versus complete data respondents), again only one significant difference was found across the seven variables in the 2020 data. The missing data respondents perceived higher Market Value to Potential Employers $(M=4.93)$ than the complete data respondents $(M=4.65), t=2.02(403), p<.05$. Overall, there was not sufficient missing data 
bias (Roth, 1994) to prevent further data analyses using the complete data samples.

\subsection{Preliminary Results - 2019 and 2020 Means, Standard Deviations and Correlations}

Prior to testing the research questions testing for changes in the 2019 to 2020 data, means, standard deviations, and correlations, were computed and the results are presented in Tables 1 (2019) and Table 2 (2020) below.

Table 1. Means, standard deviations, correlations for 2019 data

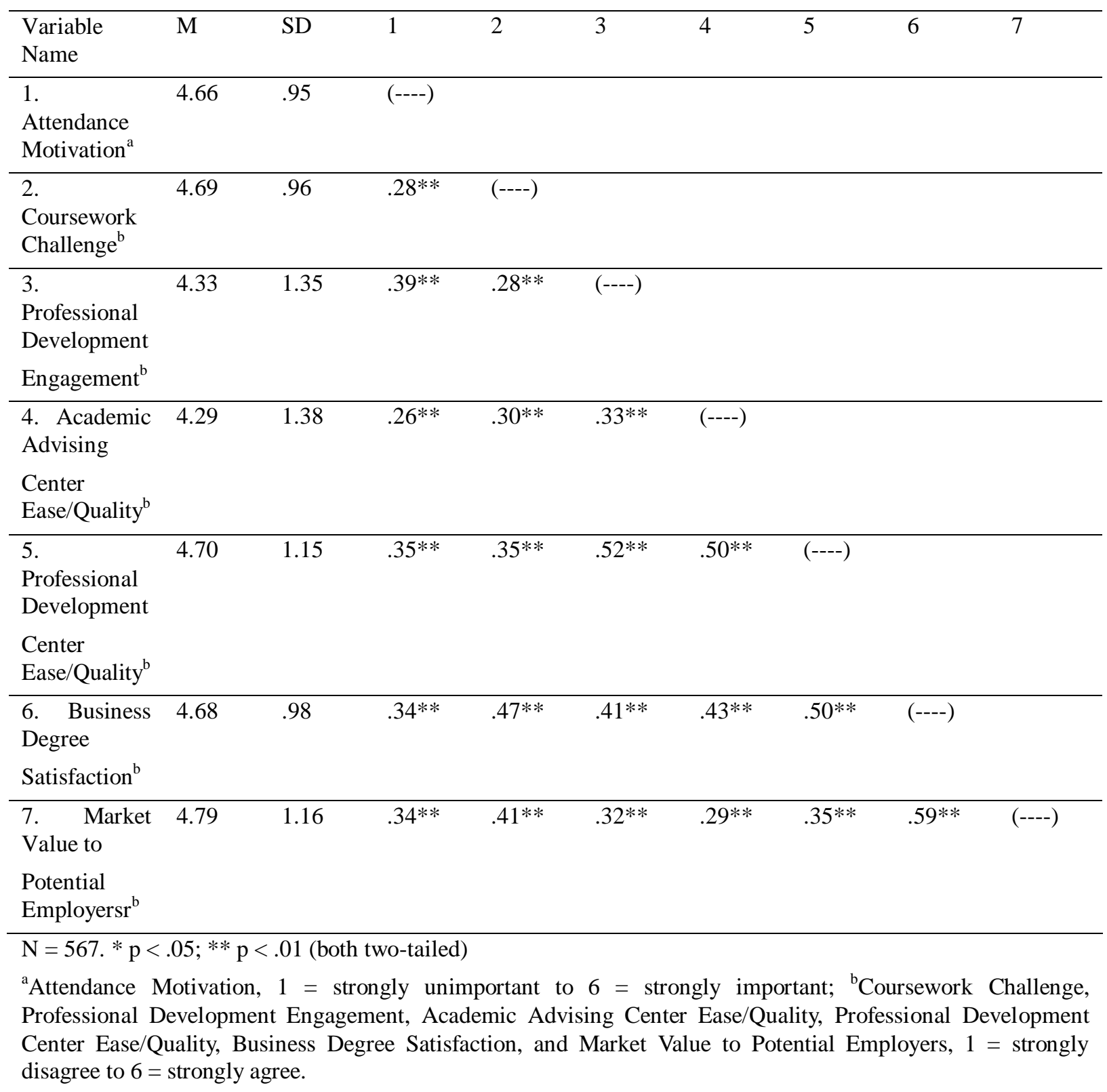

The results in Table 1 generally show moderately high mean levels across the seven variables (6-point response scale), with adequate variance. The inter-correlations among the first five variables exhibit sufficient distinctiveness to be used separately in further analyses as independent variables to Business Degree Satisfaction and Market Value to Potential Employers as dependent variables (Stevens, 1996). 
Table 2. Means, standard deviations, correlations for 2020 data

\begin{tabular}{|c|c|c|c|c|c|c|c|c|c|}
\hline $\begin{array}{l}\text { Variable } \\
\text { Name }\end{array}$ & $\mathrm{M}$ & SD & 1 & 2 & 3 & 4 & 5 & 6 & 7 \\
\hline $\begin{array}{l}1 . \\
\text { Attendance } \\
\text { Motivation }^{\mathrm{a}}\end{array}$ & 4.43 & .92 & $(----)$ & & & & & & \\
\hline $\begin{array}{l}2 . \\
\text { Coursework } \\
\text { Challenge }^{b}\end{array}$ & 4.73 & .95 & $.36 * *$ & $(----)$ & & & & & \\
\hline $\begin{array}{l}3 . \\
\text { Professional } \\
\text { Development } \\
\text { Engagement }^{b}\end{array}$ & 4.23 & 1.44 & $.46 * *$ & $.32 * *$ & $(----)$ & & & & \\
\hline $\begin{array}{l}\text { 4. Academic } \\
\text { Advising } \\
\text { Center } \\
\text { Ease/Quality }\end{array}$ & 4.20 & 1.43 & $.34 * *$ & $.31 * *$ & $.41 * *$ & $(----)$ & & & \\
\hline $\begin{array}{l}5 . \\
\text { Professional } \\
\text { Development } \\
\text { Center } \\
\text { Ease/Quality }\end{array}$ & 4.65 & 1.13 & $.40 *$ & $.31 * *$ & $.60 * *$ & $.59 * *$ & $(----)$ & & \\
\hline $\begin{array}{l}\text { 6. Business } \\
\text { Degree } \\
\text { Satisfaction }^{b}\end{array}$ & 4.58 & 1.08 & $.31 * *$ & $.44 * *$ & $.45 * *$ & $.53 * *$ & $.55 * *$ & $(----)$ & \\
\hline $\begin{array}{l}\text { 7. Market } \\
\text { Value to } \\
\text { Potential } \\
\text { Employersr }\end{array}$ & 4.65 & 1.30 & $.42 * *$ & $.44 *$ & $.45^{* *}$ & $.39 * *$ & $.47 * *$ & $.64 * *$ & $(----)$ \\
\hline
\end{tabular}

$\mathrm{N}=285 . * \mathrm{p}<.05 ; * * \mathrm{p}<.01$ (both two-tailed)

${ }^{a}$ Attendance Motivation, 1 = strongly unimportant to $6=$ strongly important; ${ }^{\mathrm{b}}$ Coursework Challenge, Professional Development Engagement, Academic Advising Center Ease/Quality, Professional Development Center Ease/Quality, Business Degree Satisfaction, and Market Value to Potential Employers, $1=$ strongly disagree to $6=$ strongly agree

The results in Table 2 are consistent with Table 1, i.e., moderately high mean levels across the seven variables (6-point response scale), with adequate variance. Furthermore, the inter-correlations among the first five variables exhibit sufficient distinctiveness to be used separately in further analyses as independent variables to Business Degree Satisfaction and Market Value to Potential Employers as dependent variables (Stevens, 1996).

\subsection{Tests of Research Questions}

To test the first research question, independent sample t-tests were computed between the 2019 versus 2020 variables to see if there were any significant changes. Exact $p$ values to hundredths are reported (Stevens, 1996). The results are shown in Table 3 below.

Table 3. Independent sample t-tests between 2019 and 2020 means

\begin{tabular}{|c|c|c|c|c|}
\hline & $2019(n=567)$ & $2020(n=285)$ & T-test Value & $\mathrm{P}$ value \\
\hline Variable Name & SD & SD & & \\
\hline
\end{tabular}




\begin{tabular}{lllllll}
\hline 1. Attendance Motivation $^{\mathrm{a}}$ & 4.66 & .95 & 4.43 & .92 & $\mathbf{3 . 4 1} \mathbf{*}^{*}$ & $\mathbf{p}=\mathbf{. 0 1}$ \\
\hline 2. Coursework Challenge $^{\mathrm{b}}$ & 4.69 & .96 & 4.73 & .95 & -.58 & $\mathrm{p}=.57$ \\
\hline $\begin{array}{l}\text { 3. Professional Development } \\
\text { Engagement }^{\mathrm{b}}\end{array}$ & 4.33 & 1.35 & 4.23 & 1.44 & .98 & $\mathrm{p}=.32$ \\
\hline $\begin{array}{l}\text { 4. Academic Advising } \\
\text { Center Ease/Quality }\end{array}$ & 4.29 & 1.38 & 4.20 & 1.43 & .89 & $\mathrm{p}=.37$ \\
\hline $\begin{array}{l}\text { 5. Professional Development } \\
\text { Center Ease/Quality }\end{array}$ & 4.70 & 1.15 & 4.65 & 1.13 & .60 & $\mathrm{p}=.55$ \\
\hline $\begin{array}{l}\text { 6. Business Degree } \\
\text { Satisfaction }\end{array}$ & 4.68 & .98 & 4.58 & 1.08 & 1.36 & $\mathrm{p}=.18$ \\
\hline $\begin{array}{l}\text { 7. Market Value to } \\
\text { Potential Employersr }\end{array}$ & & & & & & $\mathrm{p}=.13$ \\
\hline
\end{tabular}

$\mathrm{p}$ tests are two-tailed

${ }^{\mathrm{a}}$ Attendance Motivation, 1 = strongly unimportant to $6=$ strongly important; ${ }^{\mathrm{b}}$ Coursework Challenge, Professional Development Engagement, Academic Advising Center Ease/Quality, Professional Development Center Ease/Quality, Business Degree Satisfaction, and Market Value to Potential Employers, $1=$ strongly disagree to $6=$ strongly agree.

The results in Table 3 showed one significant change from 2019 to 2020 (bolded). There was a significant decrease in Attendance Motivation from $2019(M=4.66)$ to $2020(M=4.43), t(850)=3.41, p=.01$. For all other variables, there were no significant mean changes.

To test the second research question, independent sample t-tests were performed for changes in the perceived relationships of attendance motivation, coursework challenge, professional development engagement, academic advising center ease/quality, and professional development center ease/quality, used as "independent variables," to business degree satisfaction, and perceived market value to potential employers, used as "dependent variables." Exact $p$ values to hundredths are reported (Stevens, 1996). The results are shown in Table 4.

Table 4. T-tests for correlation changes from 2019 to 2020 on BBA satisfaction and market value to employer

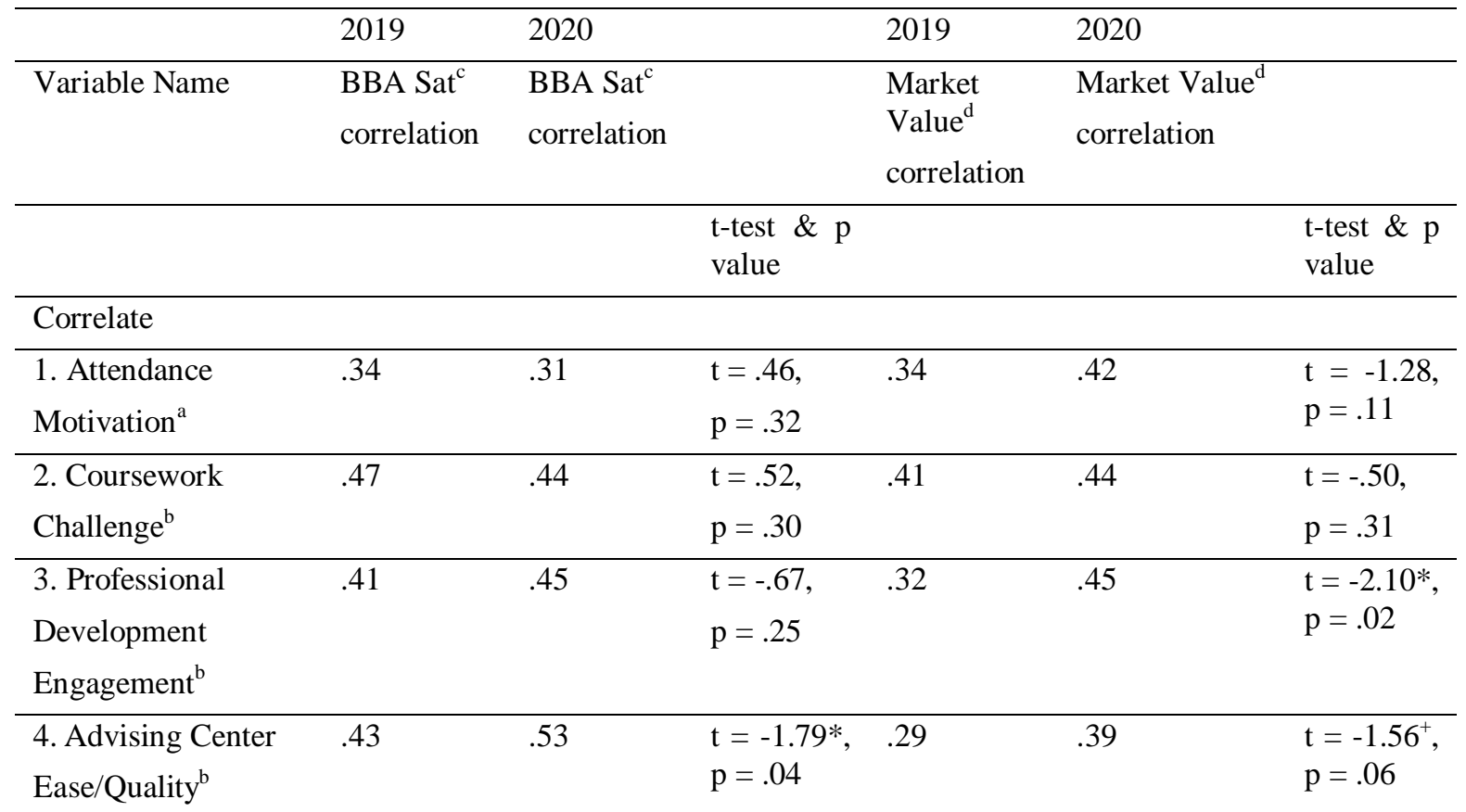




\begin{tabular}{lllllll}
\hline S.Professional & .50 & .55 & $\mathrm{t}=-.95$, & .35 & .47 & $\mathrm{t}=-1.98^{*}$, \\
Development & & $\mathrm{p}=.17$ & & & $\mathrm{p}=.02$ \\
Center & & & & & \\
Ease/Quality $^{\mathrm{b}}$ & & & & & \\
\hline
\end{tabular}

$2019 \mathrm{n}=567 ; 2020 \mathrm{n}=285$

$+\mathrm{p}<.10 ; * \mathrm{p}<.05$ (tests are two-tailed)

${ }^{\mathrm{a}}$ Attendance Motivation, 1 = strongly unimportant to $6=$ strongly important; ${ }^{\mathrm{b}}$ Coursework Challenge, Professional Development Engagement, Academic Advising Center Ease/Quality, Professional Development Center Ease/Quality; ${ }^{\mathrm{c}}$ BBA Sat $=$ Business Degree Satisfaction; ${ }^{\mathrm{d}}$ Market Value $=$ Market Value to Potential Employers, $1=$ strongly disagree to $6=$ strongly agree.

For Business Degree Satisfaction, there is one significant correlation change (bolded). The Academic Advising Center has a stronger relationship to 2020 Business Degree Satisfaction $(r=.53)$ than to 2019 Business Degree Satisfaction $(r=.43)$, i.e., $t(850)=-1.79, \mathrm{p}=.04$. For Market Value, there are two significant correlation changes (bolded). Professional Development Engagement has a stronger relationship to 2020 Market Value $(r=.45)$ than to 2019 Market Value $(r=.32), t(850)=-2.10, \mathrm{p}=.02$. Professional Development Center Ease/Quality has a stronger relationship to 2020 Market Value $(r=.47)$ than to 2019 Market Value $(r=.35), t(850)=-1.98, \mathrm{p}=.02$. Finally, there is a marginally significant correlation change for Market Value. Academic Advising Center Ease/Quality has a stronger relationship to 2020 Market Value $(r=.39)$ than to 2019 Market Value $(r=.29), t$ $(850)=-1.56, \mathrm{p}=.06$.

\section{Discussion}

Although acknowledged to be important to maintain as a college student resource during the COVID-19 pandemic (Russell et al., 2021), no prior empirical work has been done testing Academic Advising. In addition, this study expands the scope of prior empirical work of Blau et al. (2021), who demonstrated the importance of internship support to business students during the early pandemic period. There was weak support for the first research question, only Attendance Motivation changed significantly from 2019 to 2020 and it understandably decreased as students were suddenly forced to leave the main campus and all face-to-face classes were cancelled on March 13, 2020, approximately half-way through the Spring, 2020 semester. Perhaps more importantly, the results in Table 3 show a stability in all other variable means from 2019 to 2020, suggesting that despite the onset of the pandemic, professors maintained coursework challenges, and the Academic Advising Center and the Professional Development Centers both maintained positive stable ease/quality mean levels of student perceptions. In addition, the mean levels of Professional Development Engagement, Business Degree Satisfaction, and Market Value to Potential Employers also remained positively stable. Specific activities within Professional Development Engagement (e.g., resume critiquing, posting internship and job applications) are part of the responsibility of the Professional Development Center.

To further explore student perceived Business Degree Satisfaction and Market Value to Potential Employers, these measures became "dependent variables," and the other five variables became "independent variables" in correlational analyses. Tests for significant correlational changes from 2019 to 2020 to both dependent variables showed that the Academic Advising Center strengthened the relationships to Business Degree Satisfaction and Market Value to Potential Employers from 2019 to 2020. In addition, the Professional Development Center strengthened the relationship to Market Value to Potential Employers from 2019 to 2020. Collectively, all these results strongly suggest that both the Academic Advising Center and Professional Development Center responded well on these student variable perceptions early in the pandemic.

When the pandemic forced graduating business students to move out March 13, 2020, both the Academic Advising Center and Professional Development Center quickly adapted. Both Centers switched over to new remote ways of operating. They adapted their delivery modes to students from face-to-face (e.g., front desks) to $100 \%$ virtual models. This digital transformation included all student services (e.g., advising appointments, resume critiques, interview set-ups, employer recruitment functions), and fully functioning virtual front desks using Zoom. The Advising Center shifted any student graduation paper petitions to Google Forms or online submissions and provided more Zoom evening hours during busier times to facilitate student graduations. Finally, it should also be noted that the maintained stability in the mean level of Coursework Challenge was at least partially due to the quick training and resources given to faculty to transition from face-to-face to online courses 
(using Zoom) by the Business School Instructional Design Department. This is consistent with prior research showing the sudden shift in teaching to online learning with the pandemic onset (Rapanta et al., 2020).

\subsection{Study Limitations}

There are study limitations to acknowledge. The dramatic decrease in sample size (participation percentage) from $2019, \mathrm{n}=749(70 \%)$ to $2020, \mathrm{n}=445(37 \%)$, when the pandemic first began, was understandable but still troubling, with even fewer complete data size samples, $n=567$ (2019) and $n=285$ (2020). This decrease, and concern about a continued graduating student participation drop off while the pandemic was still impacting the Business School (affecting the validity of the results found), led to an upper-level administration decision not have a Spring 2021 SSSS. However, this decision prevented additional data comparison further into the pandemic. Thus this research was only able to report early pandemic student perceptions on the variables studied. The next Spring SSSS is planned to resume in 2022 under hopefully more favorable voluntary student participation conditions. Fall SSSS surveys are also done for graduating seniors, and this will resume in Fall 2021, but the 2019 and 2020 Fall SSSS sample sizes were not used because they are much smaller than the Spring sample sizes.

There are other study limitations to note. Since the SSSS is a retrospective graduation-based survey, students needed to aggregate their perceptions over time, e.g., coursework challenge, attendance motivation. All data were collected at one time point, so although Business Degree Satisfaction and Market Value to Potential Employers were classified as "dependent variables" when testing for changes in correlations, causality cannot be inferred. Method bias is a concern because only self-reported measures were used. When entering all of the items into a principal components analysis (PCA), the one-factor test for the 2019 sample found five factors, each with an eigenvalue of over 1 . Thirty-four percent of the total variance was accounted for by the first factor in the 2019 sample. For the 2020 sample, the one-factor test also found five factors with the first factor accounting for $37 \%$ of the total variance. If these first factors each represent self-report method bias, they are not an overriding study limitation (Podsakoff, MacKenzie, Lee \& Podsakoff, 2003). Spector (2006) has argued that self-report method bias does not inflate study results to a significant degree. Of course, future research efforts should try to also collect additional non-self-report or other source data (e.g., advisor and/or professional center documented student visits).

Although both samples were equivalent in terms of being full-time and their gender breakdown representation, it was not possible to compare these samples on other demographics (e.g., age, race). Participants in this study were full-time business undergraduates at a large, state-supported United States (US) urban university. Ideally, additional college student samples need to be studied, e.g., non-business, part-time, from other college settings, e.g., non-US, rural, private, etc., to test the generalizability of these variable findings.

\subsection{Conclusion}

As colleges and universities around the world grapple with the continuing impact of the ongoing pandemic, it is necessary for research to not only focus on student academic learning issues, but also on the maintained support of needed student resources such as Academic Advising and Professional Development Centers. Comparing pre-pandemic (2019) to early pandemic (2020) graduation survey data, this study collectively found that both the Academic Advising and Professional Development Centers handled student-based perception variables from these graduation surveys quite well. When the campus was closed due to the pandemic, both Centers made quick adaptive changes to virtual models to handle student needs. McCormack et al.'s (2021) recommended needs for agility and adaptability in global higher education institutions are not only important for teaching-related issues but also complementary student resources such as Academic Advising and Professional Development Centers. Given the global experience of universities dealing with the pandemic's impact (Tam et al., 2021; Watermeyer et al., 2020), ideally a collaborative effort among researchers comparing common student perception variables across different college settings, e.g., United States versus other countries, state-supported versus private, urban versus rural campus location, and full-time versus part-time undergraduates, would be ideal for future research. Such research would also overcome the above-noted study limitation by encompassing not only early pandemic but later pandemic stage data collection.

\section{References}

Agyepong, S. A., Owusu-Ansah, A., \& Annoh, W. O. (2021). Ashesi's 360 approach to the COVID-19 Pandemic. International Studies in Educational Administration (CCEA), 49(1), 78-95. Retrieved from http://hdl.handle.net/20.500.11988/596

Aspegren, E. (2021). These colleges survived World Wars, the Spanish flu and more. They couldn't withstand 
the COVID-19 pandemic. USA Today. Retrieved March 29, 2021, from https:/www.usatoday.com/story/news/education/2021/01/28/covid-19-colleges-concordia-new-york-educati on/43029800

Balakrishnan, P. (2020). Education responses in the age of COVID-19: Educational responsese from four Southeast Asian Countries. International Studies in Educational Administration (CCEA), 48(3), 102-108.

Bao, W. (2020). COVID-19 and online teaching in higher education: A case study of Peking University. Human Behavior and Emerging Technologies, 2(2), 113-115. https://doi.org/10.1002/hbe2.191

Blau, G., \& Snell, C. S. (2013). Understanding undergraduate professional development engagement and its impact. College Student Journal, 47, 689-702.

Blau, G., Halbert, T., Atwater, C., Kershner, R., \& Zuckerman, M. M. (2016). Correlates of student bachelor of business administration satisfaction and school reputation influencing perceived market value. Journal of Education for Business, 91(4), 179-184. https://doi.org/10.1080/08832323.2016.1145625

Blau, G., Snell, C., \& Goldberg, D. (2021). Reinforcing the importance of maintaining internship support for college student engagement and anticipated employment. Journal of Education and Learning, 10(1), 1-6. https://doi.org/10.5539/jel.v10n1p1

Blau, G., Williams, W., Jarrell, S., \& Nash, D. (2019). Exploring common correlates of business undergraduate satisfaction with their degree program versus expected employment. Journal of Education for Business, 94(1), 31-39. https://doi.org/10.1080/08832323.2018.1502144

Bozkurt, A., Jung, I., Xiao, J., Vladimisrschi, V., Schuwer, R., Egorov, G., .. Paskevicius, M. (2020). A global outlook to the interruption of education due to the COVID-19 Pandemic: Navigating in a time of uncertainty and crisis. Asian Journal of Distance Education, 15(1), 1-126. https://doi.org/10.5281/zenodo.3878572

Fernandez, A. A., \& Shaw, G. P. (2020). Academic leadership in a time of crisis: The coronavirus and COVID-19. Journal of Leadership Studies, 14(1), 39-45. https://doi.org/10.1002/jls.21684

Friga, B. N. (2021). How much asd Covid cost colleges? \$183 billion. The Chronicle of Higher Education. Retrieved February 5, 2021, from https:/www.chronicle.com/article/how-to-fight-covids-financial-crush

Harratian, A. M., Nordberg, H. O., Meurt, A. E., \& Ritz, T. (2021). Fear and coping in students during the earlystages of the COVID-19 Pandemic: A combined cross-sectional and longitudinal study. International Journal of Environmental Research and Public Health, 18, 6551. https://doi.org/10.3390/ijerph18126551

James Cook, S., Stokes, A., \& Parker, R. S. (2015). A 20-year examination of the perceptions of business school interns: A longitudinal case study. Journal of Education for Business, 90(2), 103-110. https://doi.org/10.1080/08832323.2014.988201

Knouse, S. B., \& Fontenot, G. (2008). Benefits of the business college internship: A research review. Journal of Employment Counseling, 45, 61-66. https://doi.org/10.1002/j.2161-1920.2008.tb00045.x

Marks, M. B., Haug, J. C., \& Hu, H. (2018). Investigating undergraduate business internships: Do supervisor and self-evaluations differ?. Journal of Education for Business, 93(2), 33-45. https://doi.org/10.1080/08832323.2017.1414025

Marshall, J., Roache, D., \& Moody-Marshall, R. (2020). Crisis leadership: A critical examination of educational leadership in higher education in the midst of the COVID-19 pandemic. International Studies in Educational Administration (CCEAM)), 48(3).

McCormack, T. J., Lemoine, P. A., Waller, R. E., \& Ichardson, M. D. (2021). Global higher education: Examining response to the COVID-19 pandemic using agility and adaptability. Journal of Education and Development, 5(1), 10-16. https://doi.org/10.20849/jed.v5i1.848

Munoz, L., Miller, R., \& Poole, S. M. (2016). Professional student organizations and experiential activities: What drives student intentions to participate?. Journal of Education for Business, 91(1), 45-51. https://doi.org/10.1080/08832323.2015.1110553

Neuwirth, L. S., Jović, S., \& Mukherji, B. R. (2020). Reimagining higher education during and post-COVID-19: Challenges and opportunities. Journal of Adult and Continuing Education. https://doi.org/10.1177/1477971420947738

Plater, R. (2021). Delta Plus, Epsilon, Gamma: New COVID-19 variants have scientists worried. Healthline. 


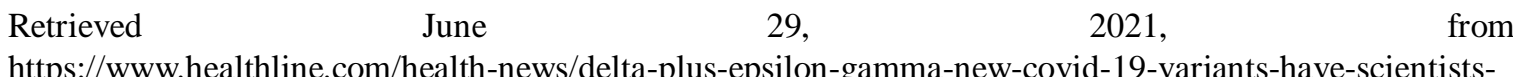
worried\#Other-worrisome-variants

Podsakoff, P., Mackenzie, S., Lee, J., \& Podsakoff, N. (2003). Common method biases in behavioral research: Critical review of the literature and recommended remedies. Journal of Applied Psychology, 88(5), 879-903. https://doi.org/10.1037/0021-9010.88.5.879

Rapanta, C., Botturi, L., Goodyear, P., Guardia, L., \& Koole, M. (2020). Online university teaching during and after the Covid-19 Crisis: Refocusing teacher presence and learning activity. Postdigital Science and Education, 2, 923-945. https://doi.org/10.1007/s42438-020-00155-y

Reeves, J. J., Longhurst, C. A., San Miguel, S. J., Juarez, R., Behymer, J., Ramotar, K. M., ... Millen, M. (2020). Bringing student health and well-being onto a health system EHR: The benefits of integration in the Covid-19 era. Journal of American College Health. Published online November 12, 2020. https://doi.org/10.1080/07448481.2020.1843468

Roth, P. (1994). Missing data: A conceptual review for applied psychologists. Personnel Psychology, 47(3), 537-560. https://doi.org/10.1111/j.1744-6570.1994.tb01736.x

Russell, W., \& Lee-Lawrence, T. (2021). A 'quality' response to COVID-19: The team experience of the Office of Quality Assurance, University of Technology, Jamaica. International Studies in Educational Administration (CCEA), 49(1), 71-77.

Sagen, H., Dallam, J., \& Laverty, J. (2000). Effects of career preparation experiences on initial employment success of college graduates. Research in Higher Education, 41(6), 753-767. https://doi.org/10.1023/A:1007072705601

Sainato, M. (2021). US universities hit by protests over cuts, tuition, right to unionize. The Guardian. Retrieved February 24, 2021, from https://www.theguardian.com/education/2021/feb/24/us-universities-protests-cuts-tuition-right-to-unionize

Spector, P. (2006). Method variance in organizational research: Truth or urban legend?. Organizational Research Methods, 9(2), 221-232. https://doi.org/10.1177/1094428105284955

SPSS-PC. Version 24. (2018). Statistical package for the social sciences. Chicago: IBM Corporation.

Stevens, J. (1996). Applied multivariate statistics for the social sciences (2nd ed.). Mahwah, NJ: Lawrence Erlbaum.

Swecker, H. K., Fifolt, M., \& Searby, L. (2013). Academic advising and first-generation colleage students: A quantitative study on student retention. NACADA Journal, 33(1), 46-53. https://doi.org/10.12930/NACADA-13-192

Tam, C. C., Li, X., Li, X., Wang, Y., \& Lin, D. (2021). Adherence to preventive behaviors among college students during COVID-19 pandemic in China: The role of health beliefs and COVID-19 stressors. Current Psychology. https://doi.org/10.1007/s12144-021-01942-x

Watermeyer, R., Crick, T., Knight, C., \& Goodall, J. (2020). COVID-19 and digital disruption in UK universities: Afflictions and affordances of emergency online migration. Higher Education, 1-19. https://doi.org/10.1007/s10734-020-00561-y

\section{Copyrights}

Copyright for this article is retained by the author(s), with first publication rights granted to the journal.

This is an open-access article distributed under the terms and conditions of the Creative Commons Attribution license (http://creativecommons.org/licenses/by/4.0/). 